\title{
Association of Thioautotrophic Bacteria with Deep-Sea Sponges
}

\author{
Miyuki Nishijima • Dhugal J. Lindsay • Junko Hata • Aoi Nakamura • Hiroaki Kasai • \\ Yuji Ise • Charles R. Fisher • Yoshihiro Fujiwara • Masaru Kawato • \\ Tadashi Maruyama
}

Received: 1 February 2009/Accepted: 12 December 2009/Published online: 11 March 2010

(C) The Author(s) 2010. This article is published with open access at Springerlink.com

\begin{abstract}
We investigated microorganisms associated with a deep-sea sponge, Characella sp. (Pachastrellidae) collected at a hydrothermal vent site (686 m depth) in the Sumisu Caldera, Ogasawara Island chain, Japan, and with two sponges, Pachastrella sp. (Pachastrellidae) and an unidentified Poecilosclerida sponge, collected at an oil seep (572 m depth) in the Gulf of Mexico, using polymerase chain
\end{abstract}

Electronic supplementary material The online version of this article (doi:10.1007/s10126-009-9253-7) contains supplementary material, which is available to authorized users.

M. Nishijima $\cdot$ J. Hata $\cdot$ A. Nakamura

TechnoSuruga Laboratory Co. Ltd.,

330 Nagasaki, Shimizu-ku,

Shizuoka 424-0065, Japan

D. J. Lindsay $\cdot$ Y. Fujiwara $\cdot$ M. Kawato $\cdot$ T. Maruyama $(\bowtie)$

Marine Biodiversity Research Program,

Japan Agency for Marine-Earth Science and Technology,

Yokosuka, Kanagawa 237-0061, Japan

e-mail: tadashim@jamstec.go.jp

H. Kasai

Marine Biotechnology Institute,

Heita, Kamaishi 026-0001, Japan

Y. Ise

Misaki Marine Biological Station, University of Tokyo,

Misaki, Miura, Kanagawa 238-0225, Japan

\section{R. Fisher}

Department of Biology, Pennsylvania State University,

208, Mueller Laboratory,

University Park, PA 16802, USA

\section{Present Address:}

H. Kasai

MBI chair "Marine Bioscience" Kamaishi Research Laboratory,

Kitasato University,

Kamaishi, Iwate 026-0001, Japan reaction-denaturing gradient gel electrophoresis (PCRDGGE) directed at bacterial $16 \mathrm{~S}$ rRNA gene sequences. In the PCR-DGGE profiles, we detected a single clearly dominant band in each of the Characella sp. and the unidentified Poecilosclerida sponge. BLAST search of their sequences showed that they were most similar $(>99 \%$ identity) to those of the gammaproteobacterial thioautotrophic symbionts of deep-sea bivalves from hydrothermal vents, Bathymodiolus spp. Phylogenetic analysis of the nearfull length sequences of the 16S rRNA genes cloned from the unidentified Poecilosclerida sponge and Characella sp. confirmed that they were closely related to thioautotrophic symbionts. Although associations between sponges and methanotrophic bacteria have been reported previously, this is the first report of a possible stable association between sponges and thioautotrophic bacteria.

Keywords Deep sea Sponge Thioautotrophic bacteria . Associated bacteria $\cdot$ Symbiosis

\section{Introduction}

Sponges are known from various marine environments (Siegl et al. 2008) and attract attention not only from biologists but also from natural product chemists because of the richness of bioactive substances (for a review, Sipkema et al. 2005). They are filter feeders, usually preying on microorganisms, but are also associated with microorganisms, which can account for as much as $57 \%$ of the biomass in the sponge (Willenz and Hartman 1989). In many cases, the associated microbes are thought to be sponge specific rather than just casual (Siegl et al. 2008; Taylor et al. 2007). Known microbial associates include autotrophic unicellular eukaryotic microalgae, archaea, cyanobacteria, and photo- 
synthetic bacteria as well as a variety of heterotrophic bacteria (Taylor et al. 2007).

In deep-sea environments, such as hydrothermal vents and seeps, dense communities of thioautotrophic symbiontcontaining invertebrates, e.g., vestimentiferan tubeworms and bivalves, which nutritionally depend on primary production by their symbionts, are often present (for a review, see Stewart et al. 2005). Although carnivorous sponges associated with methane-oxidizing bacteria are known from the deep sea (Vacelet et al. 1995; Vacelet et al. 1996; Vacelet and Boury-Esnault 2002), no sponge associating with thioautotrophic bacteria has yet been reported. We consider it probable that some deep-sea sponges dwelling near hydrothermal vents and/or seeps associate with thioautotrophic bacteria.

We collected a sponge in the Sumisu Caldera, Ogasawara Island chain, Japan that occurred in patches closely associated with vestimentiferan tubeworms, smelled of hydrogen sulfide, and was considered to be a prime candidate to host symbiotic thioautotrophic bacteria by one of the authors (DL). We also collected two sponges at an oil seep in the Gulf of Mexico, USA, where abundant tubeworms were also present. To examine the possibility of the presence of thioautotrophic associated bacteria in these deep-sea sponges, DNA was extracted from the sponges and analyzed using polymerase chain reaction (PCR) amplification of bacterial 16S rRNA genes in combination with denaturing gradient gel electrophoresis (DGGE). Here we provide the first evidence for an association between deep-sea sponges and thioautotrophic bacteria.

\section{Materials and Methods}

The deep-sea sponge from the Sumisu Caldera (Sumisu Caldera Sponge (SC-S)) was collected by the ROV HyperDolphin (Dive no. 84 on 10 March 2002 at $686 \mathrm{~m}$ depth) at a hydrothermal vent site within the Sumisu Caldera, Ogasawara Island chain, Japan $\left(31^{\circ} 28.1786^{\prime} \mathrm{N}, 140^{\circ} 04\right.$. $2580^{\prime}$ E) (Fig. S1A and B, Table 1). Sponge patches occurred with vestimentiferan tubeworm patches, and the collected sponges smelled strongly of hydrogen sulfide. After collection, sponges were rinsed with seawater and frozen at $-80^{\circ} \mathrm{C}$. For a taxonomic examination, some parts of the sponge were preserved in hexamine-saturated $10 \%$ formalin-seawater ( $\mathrm{pH} 7.5$; Wako Pure Chemical Industries, Osaka, Japan). By morphological examination of spicules and spicule arrangement, the sponge was found to belong to the genus Characella (Order, Astrophorida; Family, Pachastrellidae) according to Maldonado (2002). Molecular identification using col (cytochrome oxydase subunit 1 gene: accession no. AB453834) agreed with this identification (Fig. S3A). This sponge is designated as Characella sp. SC-S in this study. Vestimentiferan tubeworms, Escarpia sp. E1, Lamellibrachia sp., Alaysia sp. A1, and Alaysia sp. A5, which were identified according to Kojima et al. (2003), were also collected, fixed in $70 \%$ ethanol, and stored in a freezer $\left(-80^{\circ} \mathrm{C}\right)$ until used. Deep-sea mussels, Bathymodiolus septemdierum (Bsp6 and Bsp8), were also collected at the same site. Their gills were rinsed and frozen at $-80^{\circ} \mathrm{C}$ until used.

A large white sponge [Gulf of Mexico Big White Sponge (GM-BWS); Table 1; Fig. S2A] was collected on Johnson SeaLink Dive no. 4583 on 3 September 2003 from $572 \mathrm{~m}$ depth at an oil seep site in the Gulf of Mexico $\left(27^{\circ} 25\right.$. $670^{\prime} \mathrm{N}, 93^{\circ} 35.421^{\prime} \mathrm{W}$; Fig. S2B). A small blue sponge [Gulf of Mexico Small Blue Sponge (GM-SBS); Table 1; Fig. $\mathrm{S} 2 \mathrm{C}]$ attached to the GM-BWS was also used for further analysis. From the GM-BWS, a slice (ca. $40 \mathrm{~mm}$ diameter, ca. $5 \mathrm{~mm}$ thickness) was cut out, and the surface layer (about 3 to $5 \mathrm{~mm}$ from the edge) was thereafter removed with a sterile surgical blade. The core of this slice was preserved in a DNA extraction buffer $(10 \mathrm{mM}$ Tris- $\mathrm{HCl}$, $100 \mathrm{mM}$ EDTA, pH 8.0, containing $0.5 \%$ sodium dodecyl sulfate), in which the slice was dissolved. A small portion (ca. $5 \mathrm{~mm}$ in diameter) of GM-SBS was preserved in the DNA extraction buffer. They were stored at room temperature for a month until used. For taxonomic identification, small portions of GM-BWS were fixed in $10 \%$ formalin-seawater and in $2.5 \%$ glutaraldehyde (TAAB, USA) in filtered seawater and were preserved in $70 \%$ ethanol until used. Morphological examination indicated that GM-BWS was attributable to the genus Pachastrella (Family, Pachastrellidae) according to Maldonado (2002). In the later section of this study, this sponge is designated as Pachastrella sp. GM-BWS. Molecular identification of this sponge was not possible because no amplicon was obtained by PCR for either the col or the 18S rRNA gene with any of several primer sets. Taxonomic identification was not possible for GM-SBS because all GM-SBS samples were used for DNA extraction. However, phylogenetic analyses based on $\mathrm{col}$ (accession no. AB453833; Fig. S3A) and 18S rRNA gene (accession no. AB453832; Fig. S3B) suggested that this sponge is in the order Poecilosclerida. In the later section of this study, this sponge is designated as Poecilosclerida sponge GM-SBS.

For PCR-DGGE analysis, DNA was extracted from the sponges, tubeworms, and mussels collected in the Sumisu Caldera and in the Gulf of Mexico (Table 1). Two frozen specimens of Characella sp. SC-S were cut longitudinally, and aliquots (height, width and depth $=5 \times 5 \times 2 \mathrm{~mm}$ ) of distal tip surface, distal tip internal core, mid-region surface, mid-region internal core, basal surface, and basal internal core were taken with a sterile spoon. DNA was extracted from small portions (ca. $2 \mathrm{~mm}$ diameter, $10 \mathrm{~mm}$ 


\begin{tabular}{|c|c|c|c|c|c|c|c|c|c|c|}
\hline 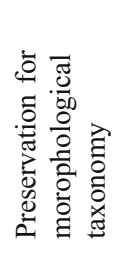 & 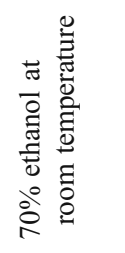 & 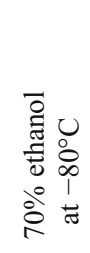 & 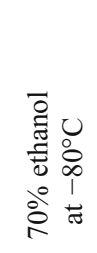 & 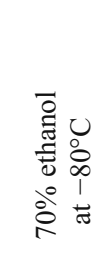 & 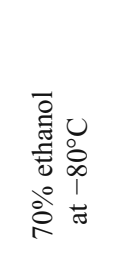 & 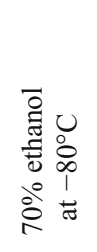 & 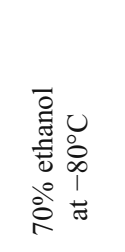 & 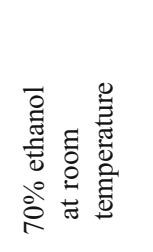 & 气̆ & \\
\hline 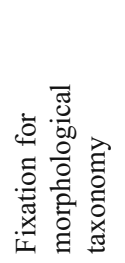 & 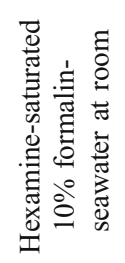 & 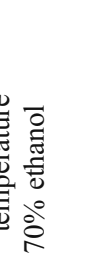 & 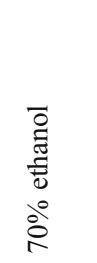 & $\begin{array}{c}\overline{0} \\
\text { 壳 } \\
\text { D } \\
\stackrel{0}{0}\end{array}$ & $\begin{array}{l}\overline{0} \\
\text { ह్ } \\
\text { है } \\
\stackrel{0}{0}\end{array}$ & $\begin{array}{l}\overline{0} \\
\text { 志 } \\
\overline{0} \\
\vdots \\
\stackrel{0}{\circ}\end{array}$ & 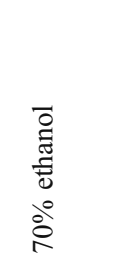 & 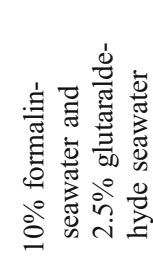 & 气̆ & \\
\hline 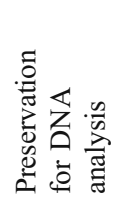 & 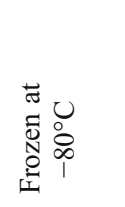 & 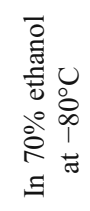 & 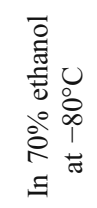 & 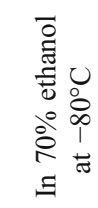 & 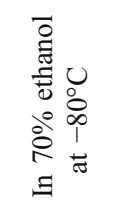 & 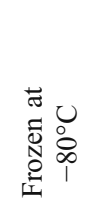 & 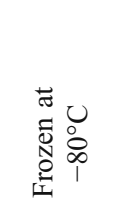 & 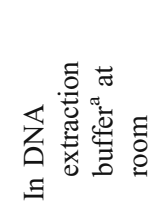 & 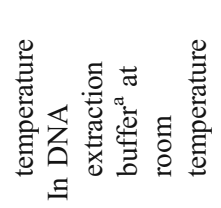 & \\
\hline 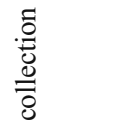 & ठे & ڤ్ & ర్ & ઠิે & ઠิ & ठิ & ઠิ & ڤ్రి & ڤ్రి & \\
\hline & $\stackrel{0}{9}$ & $\stackrel{0}{0}$ & $\stackrel{0}{0}$ & $\stackrel{0}{0}$ & $\stackrel{0}{0}$ & $\stackrel{0}{0}$ & 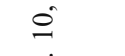 & 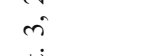 & m. & \\
\hline$\frac{\mathscr{0}}{\tilde{0}}$ & $\sum$ & $\sum$ & $\dot{\vec{\omega}}$ & $\dot{\vec{J}}$ & $\dot{\vec{J}}$ & $\dot{\vec{J}}$ & $\dot{\vec{J}}$ & 节 & 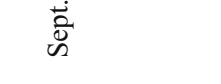 & \\
\hline 言 & $\stackrel{\circ}{\mathscr{0}}$ & $\underset{0}{0}$ & $\underset{0}{0}$ & $\underset{0}{0}$ & $\underset{0}{0}$ & $\underset{\otimes}{0}$ & $\underset{0}{0}$ & $\underset{i}{\mathbb{N}}$ & $\underset{i n}{\mathbb{N}}$ & \\
\hline 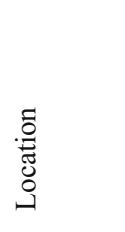 & 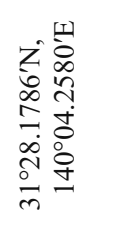 & 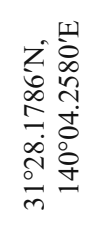 & 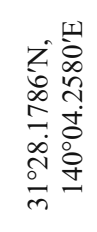 & 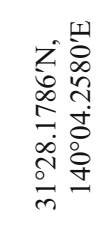 & 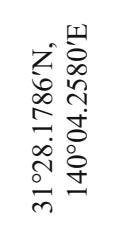 & 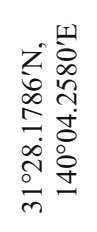 & 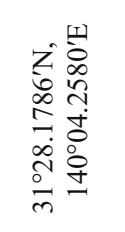 & 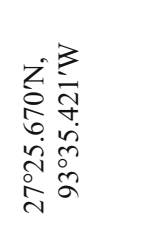 & 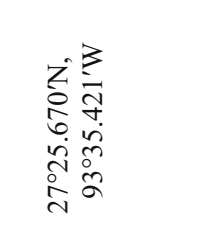 & \\
\hline 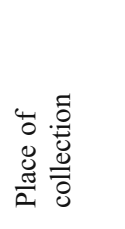 & 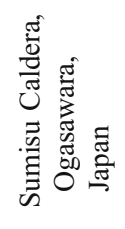 & 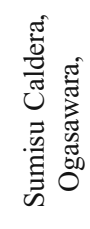 & 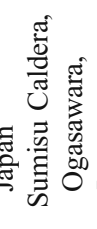 & 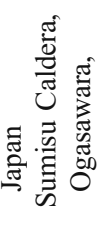 & 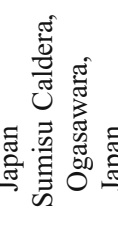 & 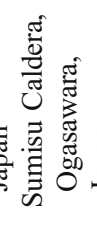 & 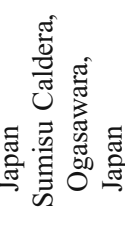 & 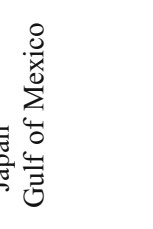 & 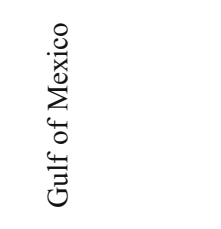 & \\
\hline 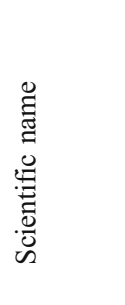 & 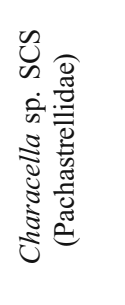 & 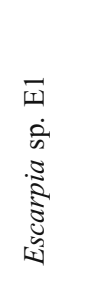 & 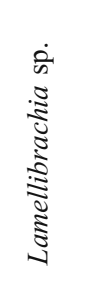 & 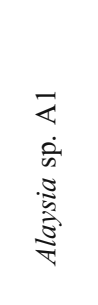 & 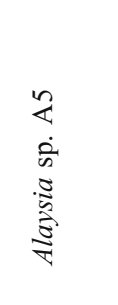 & 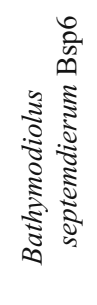 & 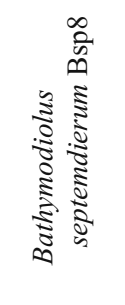 & 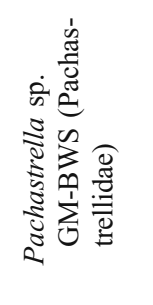 & 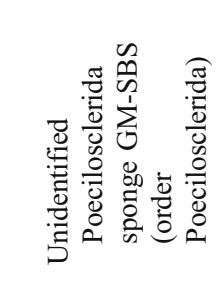 & \\
\hline & 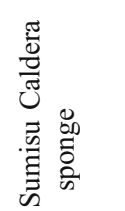 & 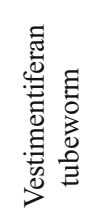 & 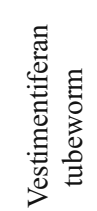 & 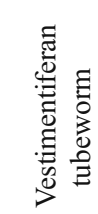 & 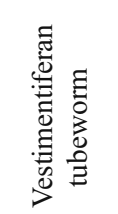 & $\begin{array}{l}\overline{\mathcal{D}} \\
\text { D. } \\
\sum^{2}\end{array}$ & 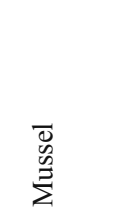 & 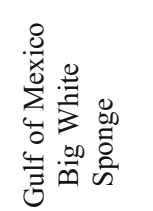 & 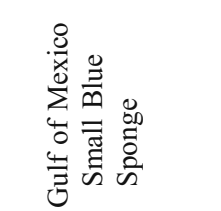 & \\
\hline
\end{tabular}


length) of the trophosomes of the vestimentiferan tubeworms and from the gills of the Bathymodiolus mussels. Pieces of the tissues were ground with an autoclaved mortar and pestle in $1 \mathrm{~mL}$ TE buffer $(10 \mathrm{mM}$ Tris- $\mathrm{HCl}, 1 \mathrm{mM}$ EDTA, $\mathrm{pH}$ 8.0) and transferred to 2-mL sample tubes. After extraction with $1 \mathrm{~mL}$ TE-saturated phenol (Nippon Gene Co. Ltd., Tokyo, Japan), they were washed with $1 \mathrm{~mL}$ phenol/chloroform/isoamylalcohol (PCI , 25:24:1), then with $1 \mathrm{~mL}$ chloroform/isoamylalcohol (24:1), and the DNA was precipitated with $1 \mathrm{~mL}$ isopropanol.

Two hundred microliters of the dissolved sample of Pachastrella sp. GM-BWS in the DNA extraction buffer was dialyzed against $10 \mathrm{~mL}$ of TE buffer for $30 \mathrm{~min}$ and then with replenished $10 \mathrm{~mL}$ TE buffer for $24 \mathrm{~h}$ at $25^{\circ} \mathrm{C}$ by using Slide-A-Lyzer $10 \mathrm{~K}$ dialysis cassettes (Pierce, IL, USA). The DNA was extracted with an equal volume of phenol, washed with an equivalent volume of PCI, and precipitated with an equivalent volume of isopropanol.

Extracted DNAs were purified with a GFX genomic blood DNA purification kit (GE Healthcare UK Ltd., UK) according to the manufacturer's instructions.

PCR-DGGE of 16S rRNA genes was carried out according to Muyzer et al. (1993). The fragments (V3 region, ca. $200 \mathrm{bp}$ ) of $16 \mathrm{~S}$ rRNA gene sequences were amplified by PCR using the primer sets (Table 2) with AmpliTaq Gold, 10× PCR buffer and dNTP AmpliTaq Gold kit (Applied Biosystems Inc. Foster City, CA, USA). For PCR, we employed a touchdown protocol: $7 \mathrm{~min}$ of Taq DNA polymerase activation at $94^{\circ} \mathrm{C}$; for the first 20 cycles, denaturation at $94^{\circ} \mathrm{C}$ for $1 \mathrm{~min}$; annealing at decreasing temperature from $65^{\circ} \mathrm{C}$ to $56^{\circ} \mathrm{C}\left(1^{\circ} \mathrm{C}\right.$ decrease for every 2 cycles) for $1 \mathrm{~min}$; extension at $72^{\circ} \mathrm{C}$ for $2 \mathrm{~min}$ : next 15 cycles; at $94^{\circ} \mathrm{C}$ for $1 \mathrm{~min}$; at $55^{\circ} \mathrm{C}$ for $1 \mathrm{~min}$; at $72^{\circ} \mathrm{C}$ for $2 \mathrm{~min}$; the final extension at $72^{\circ} \mathrm{C}$ for $10 \mathrm{~min}$ : by using GeneAmp PCR System 9600 (Applied Biosystems). For
DGGE analyses, the amplicons were analyzed by using a D-code DGGE complete system (BIO RAD, CA, USA) operated at $60^{\circ} \mathrm{C}$ for $3.5 \mathrm{~h}$ at $200 \mathrm{~V}$ in a linear $30 \%$ to $60 \%$ denaturant agent gradient $(100 \%$ denaturant agent contained $7 \mathrm{M}$ urea and $40 \%$ deionized formamide) with $10 \%$ polyacrylamide gels [polyacrylamide gel, ratio of acrylamide HG (Wako Pure Chemical Industries) to bisacrylamide (Wako Pure Chemical Industries), 37.5:1]. After DGGE, the gels were soaked for $30 \mathrm{~min}$ in SYBR Green I nucleic acid gel stain (1:10,000 dilution; Lonza, Rockland, ME, USA) and photographed on an UV transilluminator with a CCD camera.

For sequence determination of DGGE bands, bands were excised from the gel, then DNA was extracted with $100 \mu \mathrm{L}$ TE buffer and purified by ethanol precipitation. After checking the purity of the DNA by DGGE, the sequence of the purified DNA was analyzed with an ABI PRISM 3100 Genetic Analyzer System (Applied Biosystems) using a BigDye Terminator v3.1 Cycle Sequencing Kit (Applied Biosystems) and the 341f and 534r primers (Table 2).

Close to full-length 16S rRNA gene fragments of the thioautotrophic bacteria were amplified from the extracted DNA by PCR using several universal primer sets $(8 \mathrm{f}$ and 1510r for bacteria in Characella sp. SC-S and Poecilosclerida sponge GM-SBS or $8 \mathrm{f}$ and $1492 \mathrm{r}$ for bacteria in $B$. septemdierum; Table 2) and the touchdown PCR-DGGE protocol described above. Amplicons were purified by a QIAquick PCR Purification kit (QIAGEN, Hilden, Germany) and cloned with a QIAGEN PCR Cloning plus Kit according to the manufacturer's instructions. After checking inserts by PCR and electrophoresis, plasmids were purified by a QIAquick Spin Purification Kit (QIAGEN). Their nucleotide sequences were analyzed with an ABI PRISM 3100 Genetic Analyzer System (Applied Biosystems) using a BigDye Terminator v3.1 Cycle

Table 2 List of primers

\begin{tabular}{|c|c|c|c|c|}
\hline Target gene/purpose & Primer & Sequence $^{\mathrm{a}}$ & Position $^{\mathrm{b}}$ & Reference \\
\hline $\begin{array}{l}\text { Bacterial 16S rDNA/ } \\
\text { PCR-DGGE }\end{array}$ & $\begin{array}{l}\text { GC- } \\
341 \mathrm{~F} \\
534 \mathrm{r}\end{array}$ & $\begin{array}{l}5^{\prime} \text {-CGCCCGCCGCGCGCGGCGGGCGGGGCGGGGGCACGGGGGG } \\
\text { CCTACGGGAGGCAGCAG-3' } \\
5^{\prime} \text {-ATT ACC GCG GCT GCT GG-3' }\end{array}$ & $\begin{array}{l}341-357 \\
534-581\end{array}$ & $\begin{array}{l}\text { Muyzer } \\
\text { et al. } 1993\end{array}$ \\
\hline \multirow[t]{4}{*}{$\begin{array}{l}\text { Bacterial } 16 \mathrm{~S} \text { rDNA/ } \\
\text { gene cloning }\end{array}$} & $8 \mathrm{f}$ & 5' -AGA GTT TGA TCC TGG CTC AG-3' & $8-27$ & $\begin{array}{l}\text { Weisburg et } \\
\text { al. } 1991\end{array}$ \\
\hline & $341 \mathrm{f}$ & 5' -CCT ACG GGA GGC AGC AG-3' & $341-357$ & $\begin{array}{r}\text { Muyzer et } \\
\text { al. } 1993\end{array}$ \\
\hline & $1492 \mathrm{r}$ & 5' -GGT TAC CTT GTT ACG ACT T-3' & $1510-1492$ & $\begin{array}{c}\text { Hiraishi } \\
1992\end{array}$ \\
\hline & $1510 \mathrm{r}$ & 5' -GGC TAC CTT GTT ACG A-3' & $1510-1495$ & $\begin{array}{l}\text { Uchino } \\
\text { et al. } 1997\end{array}$ \\
\hline
\end{tabular}

$f$ forward primer, $r$ reverse primer

${ }^{\text {a }}$ Sequence with underline, GC clamp

${ }^{\mathrm{b}}$ The numbering of position is based on 16S rDNA of Escherichia coli 
Sequencing Kit (Applied Biosystems) and the same primers as in the PCR for the sequencing reaction and specifically designed primers for sequence walking.

The most similar gene sequences to the obtained DNA sequences were searched by BLAST (Altschul et al. 1997) in GenBank. The sequences of the cloned DNAs were aligned with other sequences from the DNA databases by clustal W (Thompson et al. 1994), edited by eye with the BioEdit program (Hall 1999), and were analyzed by the neighbor-joining method with MEGA ver3.1 (Kumar et al. 2004). Reliabilities of the clusters were examined by 1,000 bootstrap re-samplings (Felsenstein 1985). Accession

a
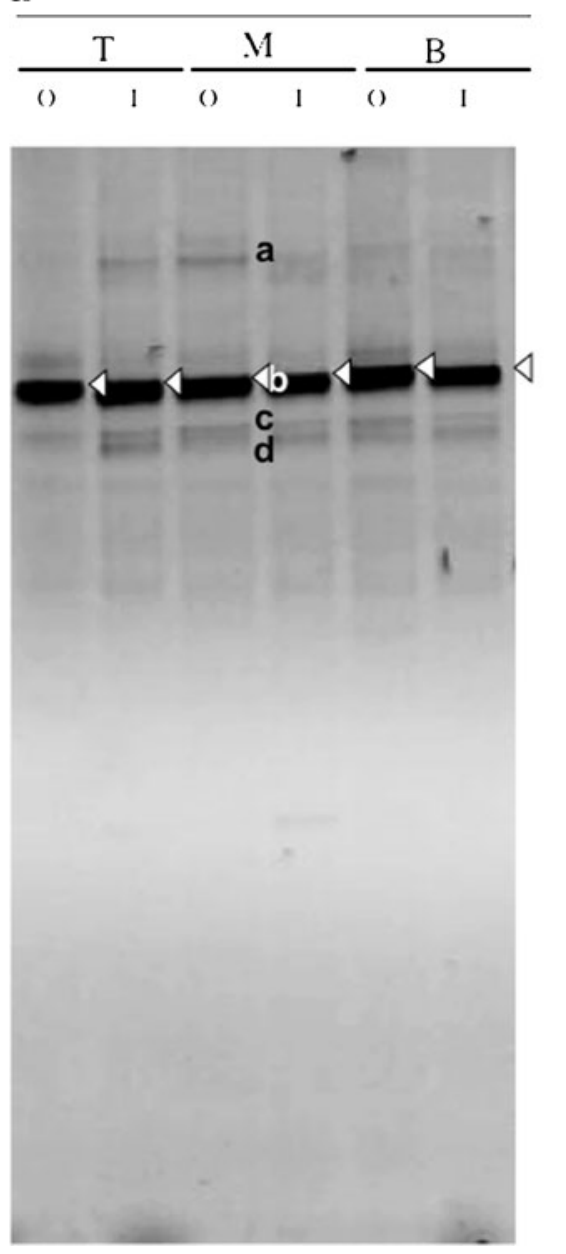

Fig. 1 DGGE profiles of the V3 region of 16S rRNA genes of the sponges from the Sumisu Caldera (a) and the Gulf of Mexico (b), which were amplified by PCR with primers, GC-341F and 534r. a Characella sp. SC-S: $O$ outside surface of the sponge, $I$ inner core, $T$ distal tip region, $M$ mid region, $B$ basal region. b Pachastrella sp. GM-BWS and Poecilosclerida sponge GM-SBS. One major band was found, respectively, in the Characella sp. SC-S and the Poecilosclerida sponge GM-SBS (arrowheads). Four major bands $(a-d)$ were detected from the Pachastrella sp. GM-BWS. Accession numbers of the bands are listed in Table S1 numbers of gene sequences of the sponges and of their associated microbes are shown in Fig. 3 and Tables S1 and $\mathrm{S} 2$.

\section{Results and Discussion}

\section{Bacteria Associated with Deep-Sea Sponges}

PCR-DGGE analysis of the bacterial 16S rRNA gene sequences obtained from the Characella $\mathrm{sp}$. SC-S showed a single major band and several minor bands (Fig. 1a). BLAST search of the DNA database (DDBJ/GenBank/ EMBL) showed that the sequences of the major bands from various parts of Characella sp. SC-S (Fig. 1a, SC-S M-O-b and corresponding bands in other lanes) were the same and most similar to that of the thioautotrophic symbiont of Bathymodiolus sp. from the Juan de Fuca vents (99\% nucleotide identity; Table S1; McKiness et al. 2005). The

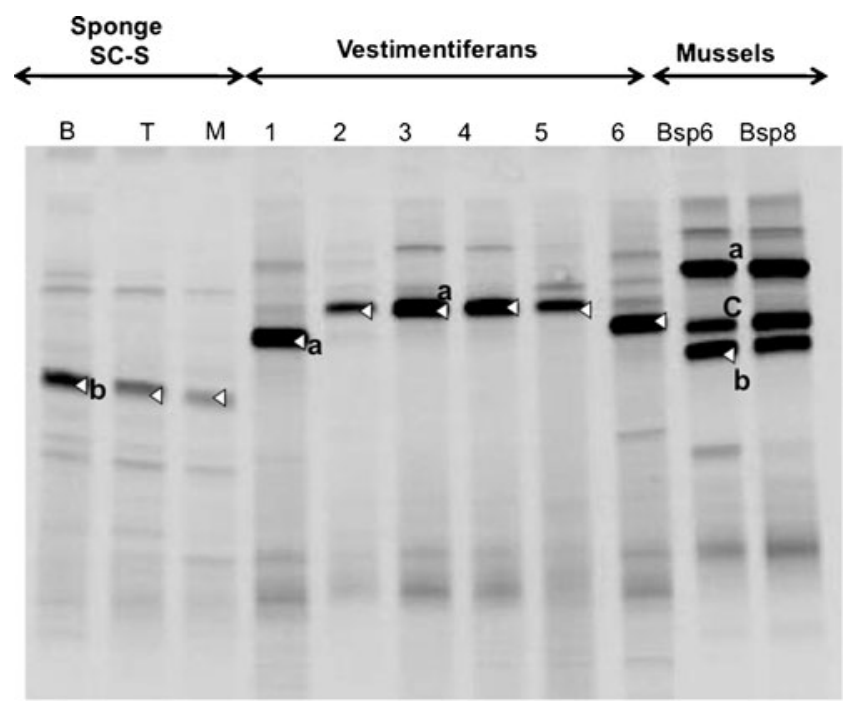

Fig. 2 DGGE profiles of V3 region of bacterial 16S rRNA gene (135-164 bp without primers) amplified by PCR with primers, GC$341 \mathrm{~F}$ and 534r, from the Characella sp. SC-S, tubeworms, and mussels collected in the Sumisu Caldera. Lanes $B, T$, and $M$, respectively, indicate the basal (outer surface), tip (outer surface), and middle (inner core) portions of the Characella sp. SC-S. Mobilities of the major bands from the different parts of the Characella sp. SC-S (band $b$ on lanes $B, T$, and $M$ ) were the same, but differed from those of the four vestimentiferan tubeworm species (arrowheads on lanes 1 to 6 ) and from those of two mussels ( $B$. septemdierum) individuals (bands $a, b$, and $c$ on lanes Bsp6 and Bsp8). Three major bands were observed from mussels but sequence analysis showed that the middle band $c$ was a mixture of sequences of $a$ and $b$. A single major band was obtained from each lane of the sponge and of the vestimentiferan tubeworms [ 1 Escarpia sp., 2 Lamellibrachia sp. (first individual), 3 Alaysia sp. A1 (first individual), 4 Alaysia sp. A1 (second individual), 5 Alaysia sp. A5, 6 Lamellibrachia sp. (second individual)]. Arrowheads Thioautotrophic symbiotic bacteria-like sequences. Small letters $a, b$, and $c$ signify excised bands (see Table S1). Accession numbers are shown in Table S1 


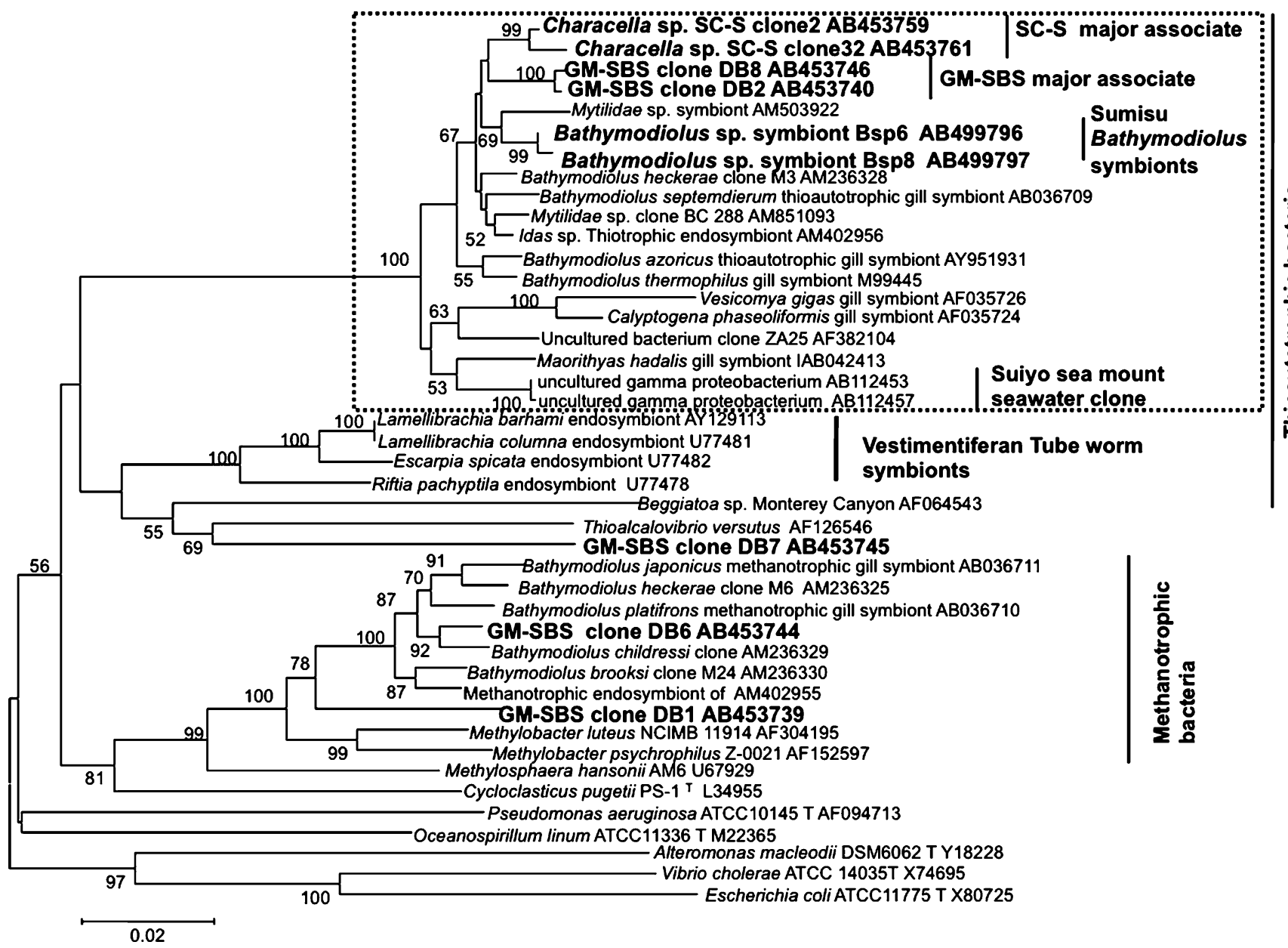

Fig. 3 Phylogenetic (neighbor-joining) tree of the nearly full length of $16 \mathrm{~S}$ rRNA gene sequences amplified by PCR and cloned from bacteria in Characella sp. SC-S, Poecilosclerida sponge GM-SBS and B. Septemdierum. Dotted line A clade containing thioautotrophic symbionts of bivalves including Bathymodiolus, Calyptogena, and Maorithyas. Accession numbers of the corresponding sequences are shown after the names of the sequences
PCR-DGGE profile of the Poecilosclerida sponge GM-SBS also showed one major band with several minor bands (Fig. 1b). The dominant band sequence (Fig. 1b, GM-SBSa) was most similar to that of the thioautotrophic symbiont of B. puteoserpentis from the Mid-Atlantic Ridge (>99\% nucleotide identity; Table S1). These data suggest that these two deep-sea sponges were associated with thioautotrophic bacteria. The PCR-DGGE profile of Pachastrella sp. GMBWS was quite different from that of the Poecilosclerida sponge GM-SBS even though the latter was attached to the former (Fig. 1b). The most prominent band in Pachastrella sp. GM-BWS (Fig. 1b, GM-BWS-a), which was not as conspicuous as that of Poecilosclerida sponge GM-SBS, was most similar to the major deltaproteobacterial sequence from the marine sponge, Discodermia dissoluta (Table S1; Schirmer et al. 2005), and no sequences similar to thioautotrophic gammaproteobacteria were detected (Table S1).
Sponges are filter feeders, and this raises the possibility that the thioautotroph-like bacteria detected in two of the sponges were derived from bacteria in the water column or in the sediment, including those that might be released by symbiont-containing invertebrates living near the sponges. In fact, the dominant planktonic bacterium at Suiyo sea mount has been reported to be similar to the symbiont of a Bathymodiolus mussel (Fig. 3, AB112453 and AB112457; Sunamura et al. 2004). To assess the possibility that the dominant bands resulted from environmental planktonic or sessile bacteria as a result of filter-feeding, DNA was extracted separately from various parts of the Characella sp. SC-S. The PCR-DGGE profiles obtained from all six portions of the Characella sp. SC-S were very similar with the single major DNA bands of the same sequences (arrowheads in Fig. 1). This indicates that the bacterial phylotype responsible for the major band was unlikely to be a contaminant. 
To further test the possibility that the dominant band in Characella sp. SC-S was an environmental contaminant, we compared the PCR-DGGE profile from the Sumisu Caldera sponge to those of the symbionts of various species of vestimentiferan tubeworms (Escarpia sp., Alyasia sp. and Lamellibrachia sp.) and a mussel species (B. septemdierum) collected from the Sumisu Caldera (Fig. 2). The major amplified band from the sponge had a different mobility from those of the tubeworm symbionts and from the three distinct bands from the mussel symbionts (Fig. 2, Table S1). These data indicate that the dominant band was not derived from filter-feeding on bacteria released from cooccurring thioautotrophic symbiont-containing organisms, or on free-living bacteria either near the sediment/seawater interface or in the water column. The most reasonable interpretation is that the dominant bacterial 16S rRNA gene phylotype in Characella sp. SC-S was an associated bacterium specific to this sponge. Two sponges from the Gulf of Mexico, the Pachastrella sp. GM-BWS and the Poecilosclerida sponge GM-SBS, which were collected as a single mass, had very different bacterial $16 \mathrm{~S}$ rRNA gene DGGE profiles (Fig. 1b), even though the microbiota in their surrounding environments would almost certainly be the same. These data strongly support the hypothesis that the primary band in the PCR-DGGE of Poecilosclerida sponge GM-SBS was also not derived from an environmental bacterium, but rather from an associated bacterium specific to this sponge.

To obtain the nearly complete length of the $16 \mathrm{~S}$ rRNA gene of the thioautotrophic associates from Poecilosclerida sponge GM-SBS, 10 clones were sequenced. In a neighborjoining phylogenetic tree of the 16S rRNA gene sequences (Fig. 3), six of the clones out of 10 together with clones from Characella sp. SC-S (clones 2 and 32) formed a clade with thioautotrophic bivalve symbionts (Fig. 3, GM-SBS clones DB2 and DB8; Table S2, GM-SBS clones DB3-5 and DB10). Two clones from Poecilosclerida sponge GMSBS formed a clade with those of free-living and symbiotic methanotrophs (Fig. 3, GM-SBS clones DB1 and 6). Of the remaining two clones, one was most similar to that of a gammaproteobacterium (Fig. 3, GM-SBS clone DB7) and the other to that of an alphaproteobacterium (Table S2, GM-SBS clone DB12).

Phylogenetic analyses of the bacterial sequences suggest that the dominant bacteria in both Characella sp. SC-S and Poecilosclerida sponge GM-SBS were thioautotrophic bacteria belonging to the Gammaproteobacteria (Fig. 3). Furthermore, these dominant bacteria in the two different sponge species, Characella sp. SC-S and Poecilosclerida sponge GM-SBS, which were sampled at widely separated locations in different geological settings and in different oceans, were quite closely related to each other. Taken together, the data presented here strongly suggest the occurrence of thioautotrophic-associated bacteria in sponges from both seeps and vents. Future studies demonstrating sulfur oxidation and/or inorganic carbon fixation by intact sponges, or detection of genes involved in these processes coupled with evidence of fixed carbon exchange between the putative associated bacteria and the sponge, will be necessary to demonstrate a nutritional chemoautotrophic symbiosis.

A methanotroph-like 16S rRNA gene sequence was identified in two of the ten clones from Poecilosclerida sponge GM-SBS (Fig. 3). Dual symbiosis with both methanotrophic and thioautotrophic bacteria has been reported previously in Bathymodiolus mussels (Distel et al. 1995; Fisher et al., 1993), and the possibility of such a dual symbiosis in this sponge deserves further study.

Acknowledgments We would like to thank the captains and crews of the R/Vs Kaiyo and Seward Johnson and the operation teams of the Johnson Sea-Link submersible and of the ROV Hyper-Dolphin. Dr. David Julian of the University of Florida is acknowledged for collecting sponges in his dive, JSL no. 4583 in the Gulf of Mexico. We are grateful to Ms. Yukiko Itazawa for her skillful technical assistance. The research cruise in the Gulf of Mexico was supported by NSF OCE 0117050 and a grant from the US NOAA Ocean Exploration program to CRF.

Open Access This article is distributed under the terms of the Creative Commons Attribution Noncommercial License which permits any noncommercial use, distribution, and reproduction in any medium, provided the original author(s) and source are credited.

\section{References}

Altschul SF, Madden TL, Schaffer AA, Zhang JH, Zhang Z, Miller W, Lipman DJ (1997) Gapped BLAST and PSI-BLAST: a new generation of protein database search programs. Nucl Acid Res 25:3389-3402

Distel DL, Lee HKW, Cavanaugh CM (1995) Intracellular coexistence of methanotrophic and thiotrophic bacteria in a hydrothermal vent mussel. Proc Natl Acad Sci USA 92:9598-9602

Felsenstein J (1985) Confidence-limits on phylogenies - an approach using bootstrap. Evol 39:783-791

Fisher CR, Brooks JM, Vodenichar J, Zande J, Childress JJ, Burke RA Jr (1993) The co-occurrence of methanotrophic and chemoautotrophic sulfur-oxidizing bacterial symbionts in a deep-sea mussel. Mar Ecol 14:277-289

Hall TA (1999) BioEdit: a user-friendly biological sequence alignment editor and analysis program for Windows 95/98/NT. Nucl Acid Symp Ser 41:95-98

Hiraishi A (1992) Direct automated sequencing of 16S rDNA amplified by polymerase chain reaction from bacterial cultures without DNA purification. Lett Appl Microbiol $15: 210-213$

Kojima S, Ohta S, Yamamoto T, Yamaguchi T, Miura T, Fujiwara Y, Fujikura K, Hashimoto J (2003) Molecular taxonomy of vestimentiferans of the western Pacific, and their phylogenetic relationship to species of the eastern Pacific III. Alaysia-like vestimentiferans and relationships among families. Mar Biol 142:625-635 
Kumar S, Tamura K, Nei M (2004) MEGA3: Integrated software for molecular evolutionary genetics analysis and sequence alignment. Brief Bioinform 5:150-163

Maldonado M (2002) Family Pachastrellidae Carter, 1875. In: Hooper JNA, van Soest RWM (eds) Systema porifera. A guide to the classification of sponges vol. 1. Kluwer, New York, pp $141-162$

McKiness ZP, McMullin ER, Fisher CR, Cavanaugh CM (2005) A new bathymodioline mussel symbiosis at the Juan de Fuca hydrothermal vents. Mar Biol 148:109-116

Muyzer G, de Waal EC, Uitterlinden AG (1993) Profiling of complex microbial-populations by denaturing gradient gel-electrophoresis analysis of polymerase chain reaction-amplified genes-coding for 16S ribosomal-RNA. Appl Environ Microbiol 59:695-700

Schirmer A, Gadkari R, Reeves CD, Ibrahim F, DeLong EF, Hutchinson CR (2005) Metagenomic analysis reveals diverse polyketide synthetase gene clusters in microorganisms associated with the marine sponge Discodermia dissoluta. Appl Environ Microbiol 71:4840-4849

Siegl A, Bayer K, Kozytska S, Hentschel U, Schmitt S (2008) Sponges and microbes-new frontiers in an ancient symbiosis. Vie et Milieu-Life Environ 58:165-174

Sipkema D, Franssen MCR, Osinga R, Tranoer J, Wijffels RH (2005) Marine sponges as pharmacy. Mar Biotechnol 7:142-162

Stewart FJ, Newton ILG, Cavanaugh CM (2005) Chemosynthetic endosymbioses: adaptations to oxic-anoxic interfaces. Trends Microbiol 13:439-448
Sunamura M, Higashi Y, Miyako C, Ishibashi J, Maruyama A (2004) Two bacteria phylotypes are predominant in the Suiyo Seamount hydrothermal plume. Appl Environ Microbiol 70:1190-1198

Taylor MW, Radax R, Steger D, Wagner M (2007) Sponge-associated microorganisms: evolution, ecology and biotechnological potential. Microbiol Mol Biol Rev 71:295-347

Thompson JD, Higgins DG, Gibson TJ (1994) Clustal-W. Improving the sensitivity of progressive multiple sequence alignment through sequence weighting, position-specific gap penalties and weight matrix choice. Nucl Acid Res 22:4673-4680

Uchino Y, Yokota A, Sugiyama J (1997) Phylogenetic position of the marine subdivision of Agrobacterium species based on $16 \mathrm{~S}$ rRNA sequence analysis. J Gen Appl Microbiol 43:243-247

Vacelet J, Boury-Esnault N, Filamedioni A, Fisher CR (1995) A methanotrophic carnivorous sponge. Nature 377:296-296

Vacelet J, Boury-Esnault N (2002) A new species of carnivorous deep-sea sponge (Demospongiae, Cladorhizidae) associated with methanotrophic bacteria. Cah Biol Mar 43:141-148

Vacelet J, Fialamedioni A, Fisher CR, Boury-Esnault N (1996) Symbiosis between methane-oxidizing bacteria and a deep-sea carnivorous cladorhizid sponge. Mar Ecol Prog Ser 145:77-85

Weisburg WG, Barns SM, Pelletier DA, Lane DJ (1991) 16S ribosomal DNA amplification for phylogenetic study. J Bacteriol 173:697-703

Willenz P, Hartman WD (1989) Micromorphology and ultrastructure of Caribbean sclerosponges. I. Ceratoporella nicholsoni and Stromatospongia norae (Ceratoporellidae Porifera). Mar Biol 103:387-402 